\title{
AL-AWQAF
}

Jurnal Wakaf dan Ekonomi Islam

Vol. 12, No. 2, Tahun 2019

\section{Survei Wakaf Hak Kekayaan Intelektual}

\section{Syifa Habibah ${ }^{1}$, Muhammad Lutfi Zuhdi ${ }^{2}$, Nurul Huda ${ }^{3 *}$}

${ }^{1}$ Universitas Indonesia, Jakarta, syifabibah@gmail.com

2 Universitas Indonesia, Jakarta

${ }_{3}^{3}$ Universitas YARSI, Jakarta, pakbuda@yahoo.com

* Corresponding author:pakhuda@yahoo.com

\begin{abstract}
This study aims to examine Intellectual Property Rights as the object of waqf. The research approach method in this paper is library research, a type of qualitative study using the document analysis method. This study is divided into four main methods, namely, the method of determining the subject, the form of the study, the method of data collection, and the method of data analysis. The findings are regarding waqf in Intellectual Property Rights as stated in Law No. 14 of 2014 concerning Waqf the categories are described in Government Regulation No. 42 of 2006 Article 21. In point $\mathrm{b}$, it is explained that movable objects other than money that can be represented in Intellectual Property Rights are: a) copyright, b) brand rights, c) patent rights, d) industrial design rights, e) rights trade secrets, f) integrated circuit rights, g) protection rights of plant variates, and or other rights. Indonesian law regarding waqf categorizes Intellectual Property Rights as immaterial objects that have a value due to royalties obtained by the creator of the Intellectual Property Rights.
\end{abstract}

Keywords: Waqf, Royalty, Economic Rights, Intellectual Property Rights

Abstrak :Meluasnya harta benda yang dapat dijadikan wakaf hadir melalui lahirnya undang-undang wakaf No. 41 tahun 2004. Salah satu hal yang menarik dalam pasal 16 Undang-Undang wakaf adalah pernyertaan ketentuan yang menyatakan bahwa Hak Kekayaan Intelektual (HKI) dapat digunakan sebagai aset/harta benda wakaf. sejalan dengan Undang-unang wakaf, pada Undang-undang yang menyangkut Hak Kekayaan Intelektual juga tercantum bahwa HKI dapat dialihkan sebagai wakaf. Namun wakaf dengan harta/benda berupa Hak Kekayaan Intelektual masih sangat jarang dilakukan. Riset ini bertujuan melihat pemahaman masyarakat terhadap wakaf kekayaan intelektual dengan pendekatan Survey. Jumlah sampel sebanyak 324 Responden. Hasil penelitian ini menunjukkan bahwa dominan responden belum mengetahui mengenai wakaf HKI

Kata kunci : Wakaf,Kekayaan intelektual,survey

$$
\begin{aligned}
& \text { ملخص: ههدف هذه الدراسة إلى فحص حقوق الملكية الفكرية كموضوع للوقف. منهج نهج البحث في هذه } \\
& \text { الورقة هو البحث المكتبي ، وهو نوع من الدراسـة النوعية باستخدام طريقة تحليل المستندات تنقسم هذه }
\end{aligned}
$$

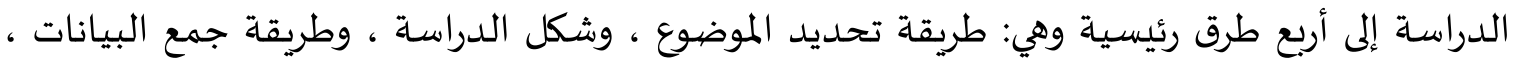

$$
\begin{aligned}
& \text { وطريقة تحليل البيانات. تتعلق النتائج بالوقف في حقوق الملكية الفكرية كما هو مذكور في القانون رقم عا }
\end{aligned}
$$




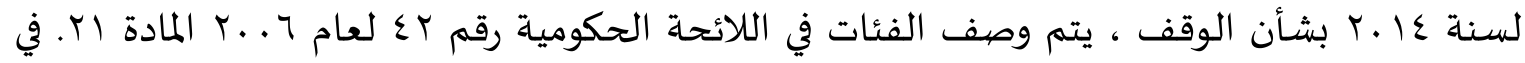
النقطة ب ، تم توضيح أن الأشياء المنقولة بخلاف النقود يمكن أن أن تكون ممثلة في حقوق الملكية الفكرية هي: أ) حقوق النشر ، ب) حقوق العلامة التجارية ، ج) حقوق براءات الاختراع ، د) حقوق التصميم الصناعي ، هـ) الأسرار التجارية للحقوق ، و) حقوق الدوائر المتكاملة ، ز) حقوق حماية المتغيرات النباتية ، أو حقوق أخرى. يصنف القانون الإندونيسي بشأن الوقف حقوق الملكية الفكرية على أنها أشياء غير مادية لها قيمة بسبب الإتاوات التي حصل عليها منشئ حقوق الملكية الفكرية.

الكلمات المفتاحية: الوقف ، الإتاوة ، الحقوق الاقتصيادية ، حقوق الملكية الفكرية

\section{Pendahuluan}

Masyarakat di Indonesia masih banyak yang memiliki pandangan bahwa wakaf hanya sebatas lahan yang akan diubah menjadi sarana peribadahan, madrasah maupun makam. Pandangan seperti itu perlu diperluas karena wakaf kini telah berkembang secara beragam dan mengedepankan produktifitas, bahkan terus mencoba berkembang menjadi modal aset milik umat yang menghasilkan dana untuk digunakan sebagai program sosial. Perkembangan menjadi aset wakaf yang produktif bukan tanpa alasan karena di Indonesia nilai aset dari tanah dan harta benda yang diwakafkan diestimasikan mencapai Rp370 Triliyun (id.undp.org) akan sayang bila tidak dimanfaatkan secara produktif sesuai dengan esensi wakaf yaitu berkembang.

Harta benda yang dapat dijadikan objek wakaf mengalami perkembangan seiring dengan zaman yang semakin maju. Selain tanah, harta yang berupa uang dan saham juga dapat diwakafkan. Dengan begitu syarat harta wakaf harus tetap/kekal (tidak habis) zatnya (ma'a baqa' 'ainib), dapat alternatif lain yakni tetap/kekal (tidak habis) nilai pokoknya (ma'a baqa' asblib) (Mubarok dan Hasanuddin, 2017). Adanya perluasan objek wakaf, yang tidak hanya meliputi benda tetap atau tidak bergerak melainkan juga benda bergerak mengandung pemikiran tentang objek wakaf yang menjadi semakin luas dan harus diapresiasi karena dengan begitu kesejahteraan umat yang diharapan akan terwujud melalui wakaf menjadi semakin terbuka lebar.

Gagasan wakaf benda bergerak muncul pada tahun 2004 dengan lahirnya Undang-undang Nomor 41 tahun 2004 tentang Wakaf. Hadirnya regulasi serta perundangan-undangan wakaf merupakan penyempurnaan dari peraturan wakaf yang sudah ada dengan ditambah hal baru sebagai upaya pemberdayaan wakaf secara produktif dan profesional. Salah satu hal yang menarik dalam Pasal 16 UU No. 41 Tahun 2004 itu adalah penyertaan ketentuan yang menyatakan bahwa Hak Kekayaan Intelektual (HKI) dapat digunakan sebagai aset/ harta benda wakaf.

Undang-Undang wakaf No. 41 tahun 2004 dalam pasal 21 huruf (b) disebutkan benda bergerak selain uang yang dapat diwakafkan sepanjang tidak bertentangan dengan prinsip syariah meliputi Hak Atas Kekayaan Intelektual yang berupa:

1) Hak cipta;

2) Hak merek;

3) Hak paten; 
4) Hak desain industri

5) Hak rahasia dagang;

6) Hak sirkuit terpadu;

7) Hak perlindungan varietas tanaman; dan atau

8) Hak lainnya.

Pengetahuan dan pemahaman mengenai jenis-jenis wakaf yang sesuai Undang-Undang No. 41 Tentang Wakaf merupakan sesuatu yang sangat penting. Bloom dalam (Ekawaty, et al.2015) dengan teorinya menjadikan pemahaman bagian dari ranah kognitif level 2 setelah pengetahuan. Pemahaman dapat diartikan sebagai kemampuan seseorang untuk mengerti sesuatu setelah diketahui dan diingat. pemahaman dipengaruhi oleh dua faktor yakni faktor dari dalam diri meliputi usia, pengalaman, intelegensia dan jenis kelamin. Faktor yang kedua yaitu faktor eksternal yang berasal dari pendidikan, pekerjaan, pengaruh lingkungan sosial budaya dan ekonomi serta informasi-informasi yang didapatkan.

Penelitian mengenai pemahaman masyarkat tentang wakaf telah banyak dilakukan yang hasilnya rata-rata pemahaman menjadi faktor signifikan yang berpengaruh dalam melakukan wakaf (Nizar, 2014; Ekawaty et al., 2015; Mochtar, 2016; Majid, 2017; Kadir et al., 2018; Huda et al., 2019). Penelitian Ekawaty et al. (2015) tentang tingkat pemahaman masyarakat Muslim Surabaya mengenai wakaf uang menunjukkan hasil bahwa lebih dari 50\% masyarakat tidak paham mengenai wakaf uang. Faktor yang mempengaruhi pemahaman tersebut karena adanya perbedaan pendapat diantara mazhab yang dianut, dan pengetahuan masyarakat tentang wakaf yang hanya berupa benda tidak bergerak seperti tanah. Lebih lanjut tingkat pemahaman seseorang terhadap wakaf uang dipengaruhi oleh tingkat pengetahuan agama yang didapat dari ceramah maupun pendidikan formal seperti pesantren, pemahaman juga dipengaruhi oleh akses informasi yang didapat mengenai wakaf serta perbincangan didalam organisasi yang diikuti.

Hak milik HKI setelah diwakafkan menjadi milik yang tertuang pada akad wakaf yang telah disetujui oleh wakif. Hak Kekayaan Intelektual (HKI) merupakan nama lain dari Intellectual Property Right atau IPR. Istilah HKI terdiri dari tiga kata kunci, yaitu Hak, Kekayaan dan Intelektual. Landasan filosofis HKI ini dimulai sejak dikemukakannya ide penghargaan bagi pencipta maupun penemu atas kreasi intelektual yang bermanfaat bagi masyarakat dalam politik Aristolle pada masa abad ke-4 SM (Affandy, 2017). World Intellectual Property Organization (WIPO) memberikan definisi HKI sebagai "kreasi yang dihasilkan dari pikiran manusia yang meliputi: invensi, karya sastra dan seni, simbol, nama, citra dan desain yang dipergunakan dalam perdagangan” (UNESCO, 2015).

Hukum Islam memang tidak mengatur hak kekayaan intelektual secara rinci dan tepat seperti dalam hal pembahasan ibadah atau warisan. Sebagai muslim kita wajib percaya bahwa semua properti yang ada di bumi ini adalah milik Allah SWT manusia hanya sebagai wali amanat yang dititipi. Namun demikian, Islam menghargai kepemilikan pribadi sebagaimana dalam QS. Al-Baqarah : 188 yang artinya "Dan janganlah sebagian kamu memakan harta sebagabian yang lai diantara kamu dengan jalan yang bathil dan jangalah kamu membawa urusan harta itu kepada hakim, supaya kamu dapat memakan sebabagian daripada harta benda orang lain itu dengan jalan berbuat dosa, padahal kamu mengetahui". Namun, berbagai sumber hukum dalam Syariah mengandung 
banyak aturan dan contoh yang membantu dalam menggambarkan hubungan antara kekayaan intelektual dengan hukum Islam.

Banindro (2015) mendefinisikan HKI sebagai suatu hak yang timbul dari hasil pola pikir manusia yang menghasilkan sebuah produk atau proses. Lebih lanjut dalam aspek hukum Saidin (2004) menjelaskan bahwa Hak Kekayaan Intelektual adalah hak kebendaan, hak atas sesuatu benda yang bersumber dari hasil kerja otak serta hasil kerja rasio yang merupakan hasil dari pekerjaan rasio manusia yang menalar dan hasil kerjanya itu berupa benda immateril atau benda yang tidak berwujud. Lebih lanjut Direktorat Jendral Kekayaan Intelektual Indonesia menyatakan intinya HKI adalah hak untuk menikmati secara ekonomis hasil dari suatu kreativitas intelektual.

Pengenalan HKI sebagaimana Banindro (2015) menjelaskan bahwa di Asia telah ada sejak sekitar tahun 1970 dan disosialisasikan melalui bacaan/literatur popular. HKI di Indonesia baru diundangkan tahun 1980 dalam bentuk lembaran negara dan tahun 2000an ditetapkan sebagai Undang-undang HKI. Sistem HKI merupakan hak privat (private rights). Disinilah ciri khas HKI karena seseorang bebas untuk mengajukan permohonan atau mendaftarkan karya intelektualnya atau tidak. Hak eksklusif yang diberikan oleh negara kepada individu pelaku HKI (inventor, pencipta, pendesain dan sebagainya tiada lain dimaksudkan sebagai penghargaan atas hasil karyanya dan agar orang lain termotivasi untuk dapat lebih lanjut mengembangkannya lagi. Disamping itu sistem HKI menunjang diadakannya sistem dokumentasi yang baik atas segala bentuk kreativitas manusia sehingga kemungkinan dihasilkannya teknologi atau hasil karya yang sama dapat terhindar dan dicegah.

Ulama pada umumnya berpendapat bahwa benda yang diwakafkan zatnya harus kekal. Namun Abu Zahrah (Prihatini et al.,2005:113) mengungkapkan bahwa Imam Malik dan golongan Syi'ah Imamiah menyatakan wakaf itu boleh dibatasi waktunya. Sebagian besar ulama sepakat bahwa harta yang diwakafkan harus mutaqawnim artinya barang yang harus dimiliki seseorang dan barang yang dimiliki itu boleh dimanfaatkan menurut Syari'at (Islam) dalam keadaan apapun, misalnya kitab atau buku dan barang tidak bergerak. Manfaat suatu benda saja tidak bisa diwakafkan karena maksud wakaf adalah pengambilan manfaat zat oleh manquf alaih dan pahala bagi wakif. Untuk itu menurut Makdur yang dikutip oleh Abdul Manan (Prihatini et al., 2005:112) zat wakaf harus tetap dan dapat dimanfaatkan untuk jangka waktu yang lama, tidak habis dipakai. Pada intinya harta yang diwakafkan harus mempunyai nilai ekonomis, halal, tetap zatnya dan dapat dimanfaatkan terus menerus. Adanya wakaf kekayaan inteletual merupakan praktik wakaf modern dari aset tidak berwujud yang dapat dimanfaatkan terus menerus dan tidak dapat diperdagangkan (Abdullah, 2018)

Wakaf untuk selamanya (mu'abbad) dan untuk sementara waktu (mu'aqqat) pada prinsipnya tidak lepas dari pemahaman ulama mengenai sifat akad wakaf (apakah bersifat al-tamlik atau bersifat al-ibahah). Berkaitan dengan hal tersebut, ulama mempunyai beberapa perbedaan pendapat antara lain (Mubarok \& Hasanuddin, 2017:273-274):

1) Imam Syafi'i berpendapat (termasuk jumhur ulama) bahwa akad wakaf termasuk akad lazim. Oleh karena itu, benda yang telah diwakafkan bukan lagi milik wakif, ia telah berpindah menjadi milik umum (atau milik Allah). Akibatnya adalah bahwa benda yang 
telah diwakafkan tidak boleh dijual, dihibahkan, dan diwariskan karena memang bukan milik perorangan lagi melainkan milik publik (umat).

2) Ulama Malikiah mengakui bahwa wakaf dapat dilakukan untuk selama-lamanya dan dapat pula dilakukan hanya untuk waktu tertentu. Argumentasi ulama Malikiah mengenai kepemilikan wakaf dan wakaf dalam durasi tertentu berdasarkan pemahaman hadis dan qiyas (analogi). Dalam hadis Ibn Umar diriwayatkan oleh Bukhari dan Muslim dijelaskan bahwa Nabi SAW. Bersabda:

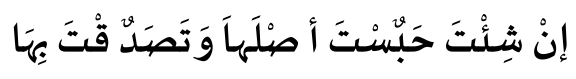

"Jika engkau berkenan, tahanlah pokoknya dan engkau sedekahkanlah hasilnya".

Hadis tersebut, menurut ulama Malikiah, mengisyaratkan bahwa benda wakaf masih tetap menjadi milik wakif dan yang disedekahkan adalah manfaatnya. kemudian wakaf dipandang sama dengan al-hijr (pengampunan atau perwalian) karena pemilik harta tertimpa sifat boros. Harta yang diurus oleh pengampu atau wali masih tetap milik yang diampunya. Harta yang diampunya tidak boleh dijual atau dihibahkan kepada oranglain.

3) Ulama Hanafiah mengakui bahwa akad wakaf tidak menyebabkan kepemilikan objeknya berpindah (masih tetap milik wakif, sebagaimana akad pinjam (al-ariyah) kecuali empat wakaf yakni wakaf untuk masjid, wakaf yang ditetapkan dengan keputusan hakim, wakaf wasiat dan wakaf untuk kuburan (makam).

Uraian di atas menjadi dasar latar belakang penulisan artikel ini. Sehingga, rumusan masalah dalam artikel ini berupa pertanyaan Bagaimana persepsi masyarakat mengenai wakaf Hak Kekayaan Intelektual ?. Rumusan masalah tersebut menjadi tujuan penulisan artikel ini untuk mengetahui hasil survey pada masyarakat mengenai wakaf Hak Kekayaan Intelektual.

\section{Metode Penelitian}

Penelitian ini menggunakan metode survei. Populasi dalam penelitian ini adalah masyarakat yang berada di wilayah Jakarta, Bogor, Depok, Tangerang, dan Bekasi (Jabodetabek). Teknik pengambilan sampel dengan menggunakan metode non probability sampling yaitu purposive sampling dengan jumlah sampel sebanyak 324 Responden.

\section{Hasil Penelitian dan Pembahasan}

Hasil penelitian ini juga menghimpun karakteristik profil responden yang terdiri atas jenis kelamin, usia, pendidikan, pekerjaan, pendapatan per bulan dan pertanyaan awal yang diajukan peneliti. Hal tersebut tertuang dalam tabel dan grafik berikut.

Tabel 1

\section{Karakteristik Profil Responden}

\begin{tabular}{|c|c|c|c|c|}
\hline \multirow{2}{*}{ No. } & \multicolumn{2}{|c|}{ Karakteristik } & $\begin{array}{c}\text { Jumlah } \\
\text { Responden }\end{array}$ & Presentase \\
\hline \multirow{2}{*}{1.} & Jenis & Laki-laki & 128 & $39.4 \%$ \\
\cline { 3 - 5 } & Kelamin & Perempuan & 196 & $60.6 \%$ \\
\hline
\end{tabular}




\begin{tabular}{|c|c|c|c|c|}
\hline \multirow{3}{*}{2.} & \multirow{3}{*}{ Usia } & $18-<25$ tahun & 139 & $43 \%$ \\
\hline & & $25-35$ tahun & 77 & $23 \%$ \\
\hline & & $>35$ tahun & 106 & $32 \%$ \\
\hline \multirow{6}{*}{3.} & \multirow{6}{*}{ Pendidikan } & SMP & 5 & $2 \%$ \\
\hline & & SMA & 47 & $14 \%$ \\
\hline & & D3 & 14 & $4 \%$ \\
\hline & & $\mathrm{D} 4 / \mathrm{S} 1$ & 182 & $56 \%$ \\
\hline & & $\mathrm{S} 2$ & 67 & $21 \%$ \\
\hline & & S3 & 9 & $3 \%$ \\
\hline \multirow{9}{*}{4.} & \multirow{9}{*}{ Pekerjaan } & Mahasiswa & 59 & $18 \%$ \\
\hline & & PNS/BUMN & 30 & $9 \%$ \\
\hline & & Guru/Dosen/Pengajar & 91 & $28 \%$ \\
\hline & & $\begin{array}{c}\text { Pegawai } \\
\text { Swasta/Pemerintahan }\end{array}$ & 73 & $22 \%$ \\
\hline & & Pekerja Seni & 1 & $<1 \%$ \\
\hline & & Insinyur/arsitek & 3 & $<1 \%$ \\
\hline & & Wirausaha & 21 & $6 \%$ \\
\hline & & Ibu Rumah Tangga & 30 & $9 \%$ \\
\hline & & Lain-lain & 16 & $6 \%$ \\
\hline \multirow{2}{*}{5} & \multirow{2}{*}{ Penghasilan } & $<$ Rp4.000.000 & 158 & $49 \%$ \\
\hline & & $>$ Rp4.000.000 & 166 & $51 \%$ \\
\hline
\end{tabular}

Sumber: Diolah (2019)

\section{Jenis Kelamin responden}

Berdasarkan hasil pengumpulan data yang diperoleh seperti yang terlihat pada tabel 1 terdapat 128 responden atau 39.4\% berjenis kelamin laki-laki dan 196 responden atau 60.6\% berjenis kelamin perempuan. Penelitian ini tidak membedakan gender secara khusus dari responden, maka mendominasinya perempuan tetap dapat diterima dan bukan merupakan variabel yang berpengaruh dalam penelitian ini.

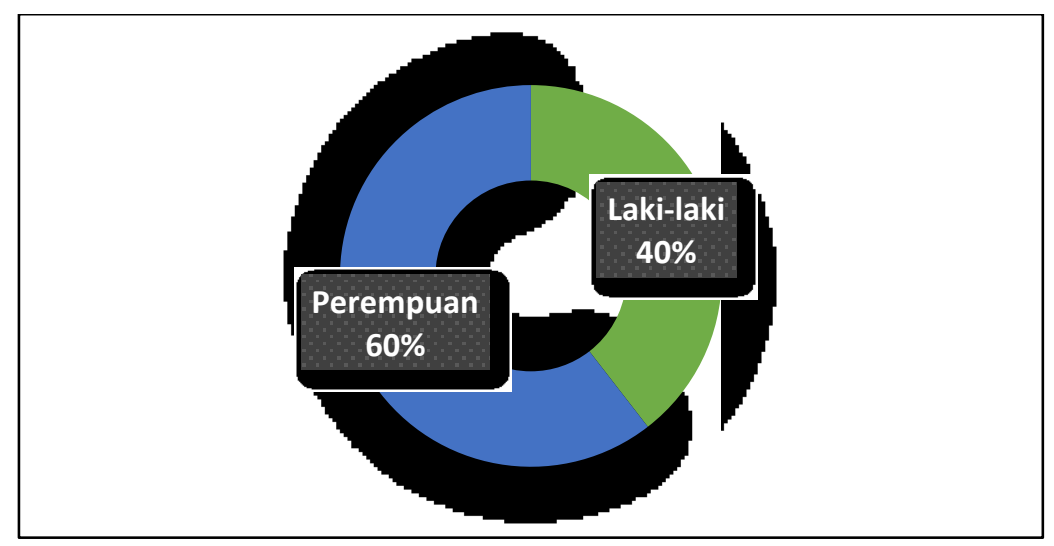

Sumber: Diolah (2019)

\section{Gambar 1 Profil Responden Berdasarkan Jenis Kelamin}




\section{Usia Responden}

Profil responden berdasarkan usia digolongkan dalam beberapa kategori, yaitu usia $18-<25$ tahun, 25 - 35 tahun, dan $>35$ tahun. Seperti yang terlihat pada tabel 4.7 responden yang paling banyak mengikuti penelitian ini adalah pada rentang usia $>35$ tahun sebanyak 139 responden, disusul oleh usia 25 - 35 tahun sebanyak 106 responden dan sisanya sebanyak 77 responden berusia $18-<24$ tahun. Usia diperhitungkan dalam beberapa penelitian seperti Huda et al. (2019) karena dalam penelitiannya mengenai partisipasi dalam wakaf uang faktor usia yang semakin bertambah akan berpengaruh pada tingkat keimanan yang nantinya akan membawa minat berpatisipasi pada berwakaf uang semakin besar. Berikut ini Gambar 2 yang menunjukkan profil responden berdasarkan usia:

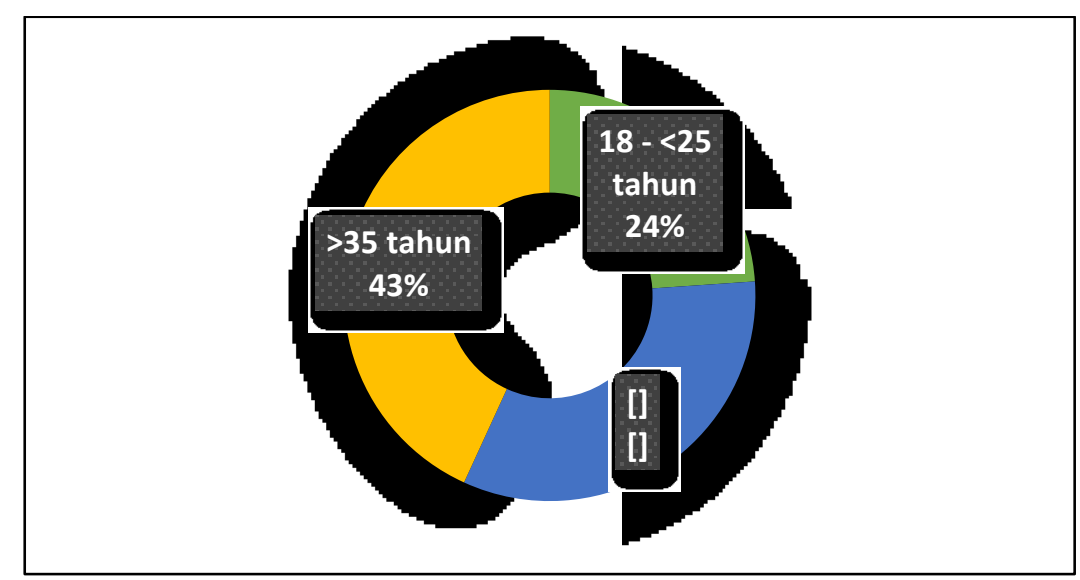

Sumber: Diolah (2019)

Gambar 2 Profil Responden berdasarkan usia

\section{Pendidikan Responden}

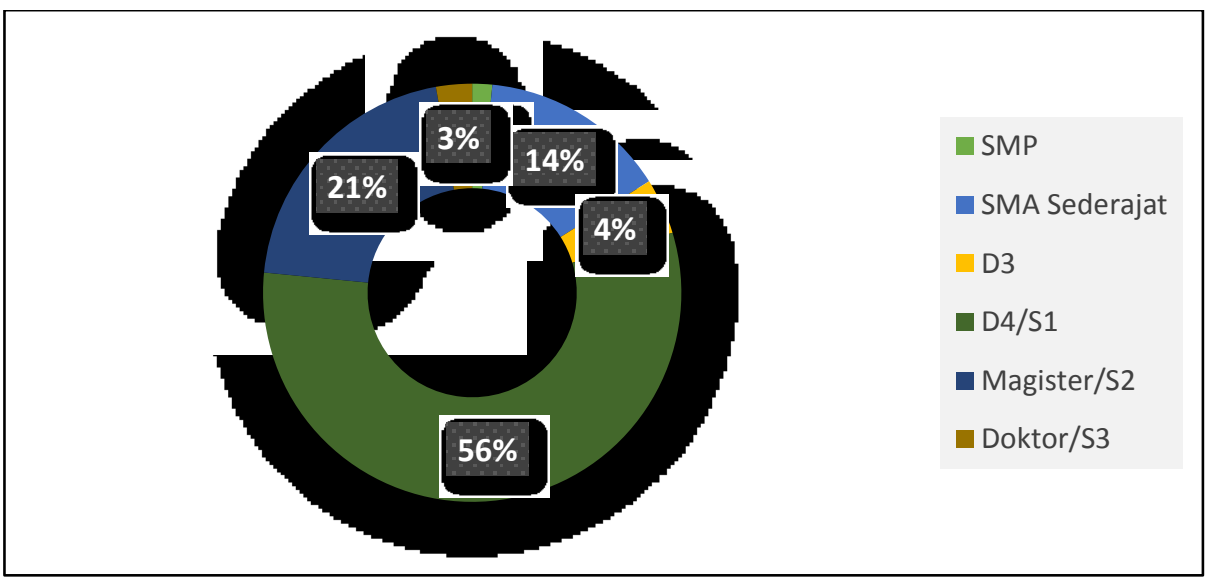

Sumber: Diolah (2019)

Gambar 3 Profil Responden Berdasarkan Jenjang Pendidikan 
Responden dalam penelitian ini mayoritas berpendidikan Sarjana/S1 sebanyak 182 orang (56\%), selanjutnya diikuti Magister/S2 sebanyak 67 orang (21\%), SMA sederajat sebanyak 47 orang (14\%), kemudian Diploma/D3 sebanyak 14 orang (4\%) dan terakhir Doktor/S3 sebanyak 9 orang $(3 \%)$ serta SMP sebanyak 5 orang (2\%). Total $80 \%$ responden dalam penelitian ini merupakan lulusan perguruan tinggi mulai jenjang sarjana hingga doktoral namun yang mendominasi adalah lulusan sarjana/S1. Penelitian ini tidak mensyaratkan jenjang pendidikan karena orang yang berwakaf maupun memilik kekayaan intelektual bisa dimiliki siapa saja asalkan penemuannya atau hasil karyanya baru, unik dan dapat bermanfaat. Dengan latar belakang pendidikan tinggi tersebut diharapkan akan mencerminkan kualitas jawaban responden yang baik. Karena pendidikan erat kaitannya dengan tingkat pengetahuan seseorang.

\section{Pekerjaan Responden}

Pekerjaan pada penelitian ini juga peneliti golongkan menjadi beberapa jenis pekerjaan secara umum termasuk mahasiswa. Profil pekerjaan responden dapat dilihat pada tabel 1 dan gambar berikut:

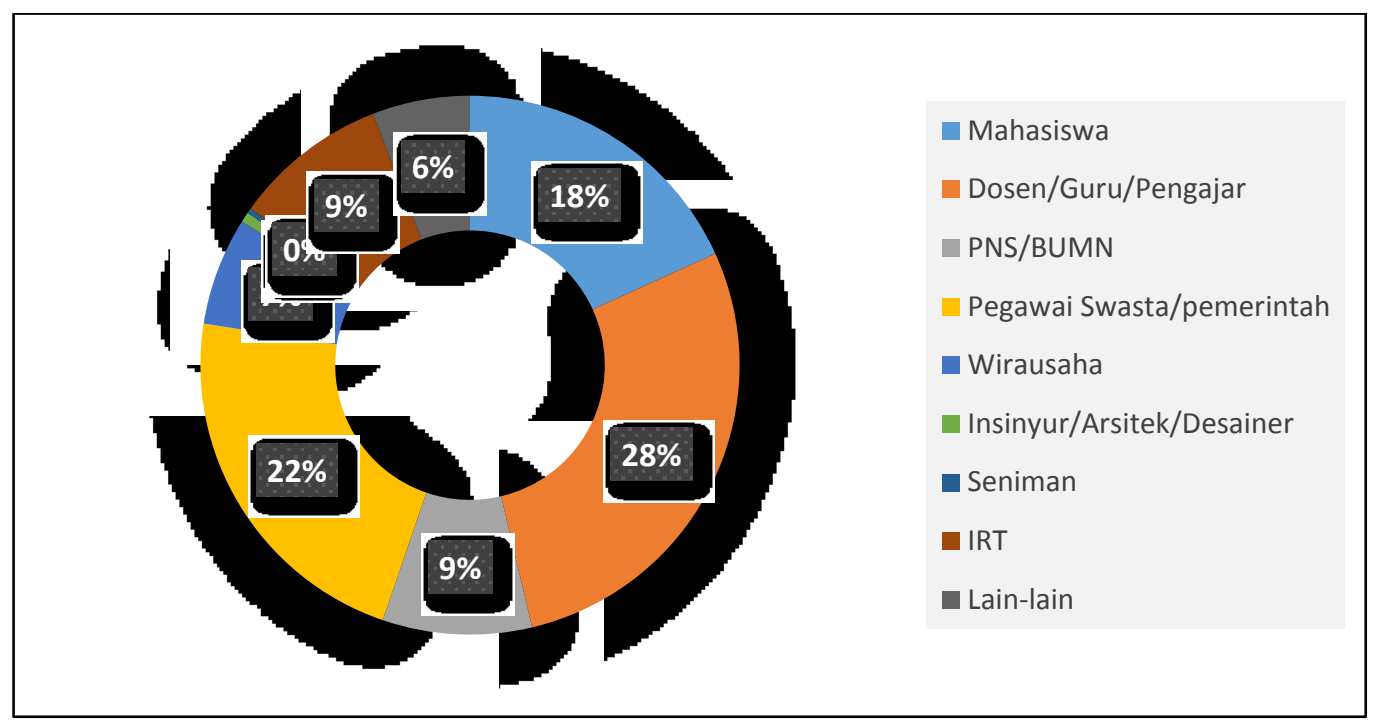

Sumber: Diolah (2019)

\section{Gambar 4 Profil Pekerjaan Responden}

Berdasarkan Tabel 1 sebelumnya dan Gambar 4 terlihat bahwa sebanyak 91 responden (28\%) bekerja sebagai pengajar baik guru maupun dosen, sekitar 22\% yaitu 72 responden bekerja sebagai pegawai baik di swasta maupun pemerintah, selanjutnya sebanyak 59 responden $(18 \%)$ adalah mahasiswa, kemudian responden yang bekerja sebagai PNS dan di BUMN sebanyak 29 responden ( $9 \%$ ) dilanjutkan oleh ibu rumah tangga sebanyak 30 responden (9\%) disusul oleh wirausaha sebanyak 21 responden $(7 \%)$ dan responden ada yang bekerja sebagai Insinyur/Arsitek/Desainer sebanyak 3 orang dan seniman 1 orang, sisanya sekitar $6 \%$ atau 16 orang memilih lain-lain. Responden dengan pekerjaan sebagai Guru/dosen/Pengajar serta 
pegawai mendominasi hal ini juga dikarenakan ruang lingkup pekerjaan peneliti yang berada di sekolah.

\section{Penghasilan responden}

Profil responden dilihat dari penghasilannya seperti yang terdapat pada tabel 1 diawal, hanya peneliti bagi menjadi dua yaitu responden berpenghasilan $<$ Rp4.000.000 dan $>$ Rp4.000.000. berikut adalah gambar 5 yang menunjukkan perbedaan penghasilan responden.

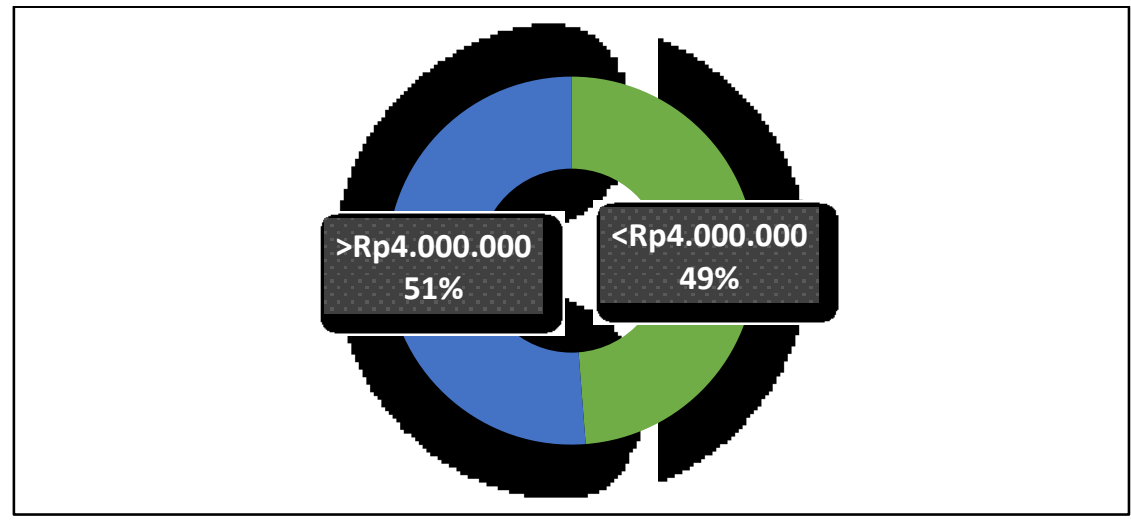

Sumber: Diolah (2019)

\section{Gambar 5 Profil penghasilan responden}

Menurut rata-rata upah minimum provinsi tahun 2019 di wilayah Jabodetabek sekitar Rp3.700.000 sampai Rp4.200.000 tertingginya. Pada penelitian ini responden berpenghasilan $<$ Rp4.000.000 terdapat 158 responden (49\%) dan sisanya sebanyak 166 responden (51\%) berepenghasilan $>$ Rp4.000.000. Perbedaan jumlah penghasilan antara jumlah responden tidak terlalu jauh hal ini pun berhubungan dengan jenis pekerjaan pada penelitian ini yang rata-rata sudah bekerja dan berpendidikan sarjana hingga doktoral.

Pertanyaan lain yang dapat menjadi informasi tambahan dalam penelitian ini adalah pertanyaan seputar pengalaman berwakaf para responden. Sebagaimana penelitian ini dilakukan yang bertujuan untuk mengetahui intensi masyarakat untuk berwakaf HKI maka peneliti mengajukan beberapa pertanyaan awal seperti apakah responden pernah mendengar tentang wakaf Hak Kekayaan Intelektual. Untuk lebih jelasnya pertanyaan pengantar beserta jawaban responden dirangkum dalam tabel 2 berikut.

Tabel 2 Tingkat Pemahaman Responden

\begin{tabular}{|l|c|c|c|}
\hline \multicolumn{1}{|c|}{ Pertanyaan } & Jawaban & $\begin{array}{c}\text { Jumlah } \\
\text { Responden }\end{array}$ & Presentase \\
\hline $\begin{array}{l}\text { Apakah Anda pernah mendengar tentang } \\
\text { Wakaf Hak Kekayaan Intelektual? }\end{array}$ & Pernah & 121 & $38 \%$ \\
\cline { 2 - 4 } & Tidak & 203 & $62 \%$ \\
\hline Apakah Anda pernah berwakaf? & Pernah & 130 & $40 \%$ \\
\cline { 2 - 4 } & Tidak & 194 & $60 \%$ \\
\hline Apakah dalam keluarga Anda pernah ada & Pernah & 245 & $76 \%$ \\
\hline
\end{tabular}




\begin{tabular}{|l|l|l|l|}
\hline yang berwakaf? & Tidak & 79 & $24 \%$ \\
\hline Sumber: Diolah (2019)
\end{tabular}

Tabel 2 diatas merangkum jawaban pertanyaan awal yang dijawab oleh responden. Untuk pertanyaan awal "Apakah Anda pernah mendengar tentang Wakaf Hak Kekayaan Intelektual?" sekitar 62\% dari 324 responden menjawab tidak pernah mendengar adanya wakaf Hak Kekayaan Intelektual dan sisanya sebanyak 121 responden atau 38\% menjawab pernah. Mayoritas jawaban responden yang tidak pernah mendengar tentang wakaf kekayaan intelektual menjadi praduga peneliti bahwa ketidaktahuan masyarakat mengenai Hak kekayaan intelektual yang dapat diwakafkan masih cukup tinggi walaupun rata-rata responden dalam penelitian ini adalah lulusan perguruan tinggi. Dari 258 responden yang sudah lulus atau sedang melaksanakan pendidikan S1, S2 dan S3 ada 112 responden (43\%) yang pernah mendengar atau mengetahui tentang wakaf Hak Kekayaan Intelektual.

Pertanyaan pengantar kedua yaitu "Apakah Anda pernah berwakaf?" pertanyaan tersebut bertujuan untuk mengetahui seberapa banyak responden yang sudah pernah melakukan wakaf. Sebanyak 130 responden (40\%) mengaku sudah pernah berwakaf dan sisanya lebih banyak belum pernah berwakaf yaitu 194 responden (60\%). Sebanyak 40\% responden yang pernah berwakaf mayoritas adalah perempuan sebanyak 72 orang dan 58 laki-laki. Selain itu 130 responden (40\%) yang pernah berwakaf 47 diantaranya $(36 \%)$ pernah mendengar tentang wakaf HKI dan sisanya 83 responden $(64 \%)$ belum pernah mendengar. Benda atau harta yang diwakafkan diantaranya memiliki variasi. Berikut jenis harta/benda yang sudah pernah diwakafkan oleh $40 \%$ responden penelitian ini.

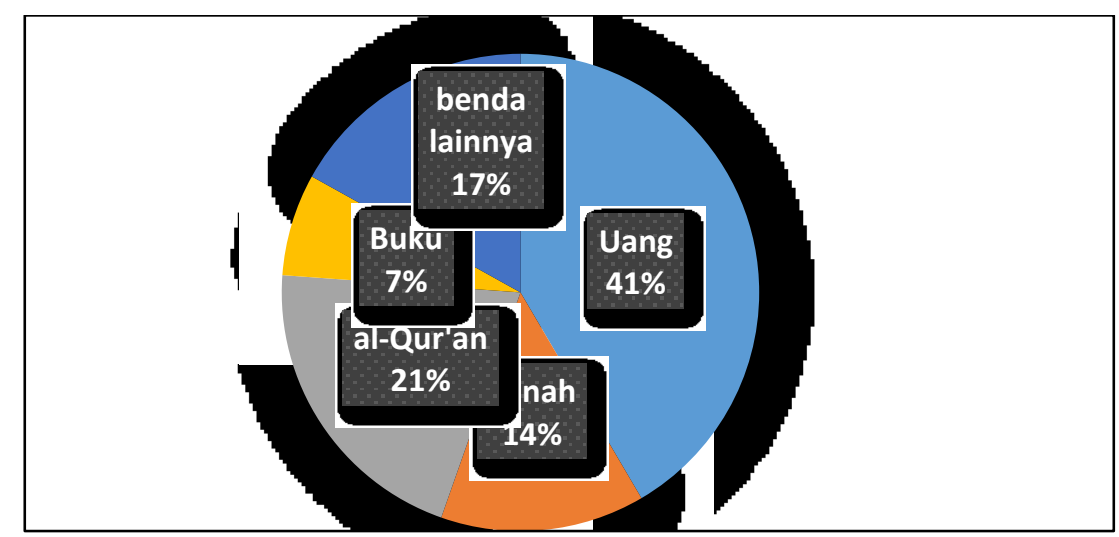

Sumber: Diolah (2019)

\section{Gambar 6 Harta benda yang pernah diwakafkan responden}

Gambar 6 diatas menunjukkan bahwa 41\% dari 130 responden yang pernah berwakaf pada penelitian ini sudah pernah berwakaf uang. Rendahnya masyarakat yang belum pernah berwakaf uang nampaknya hampir sejalan dalam penelitian sebelumnya seperti Huda et al. (2019) dari 138 responden hanya sebesar 30\% dari responden yang sudah pernah berwakaf uang namun dalam penelitian ini ada peningkatan sedikit yakni mencapai 41\%. Data tahun 2017 yang dihimpun oleh Ismawati \& Khoirul Anwar (2019) jumlah Wakaf Uang yang berhasil dihimpun baru sebesar Rp199.094.773.196 dari potensi wakaf uang pertahunnya sebesar 3 Triliyun. Kemudian 21\% responden telah mewakafkan al-Qur'an, selanjutnya 14\% telah mewakafkan tanahnya, dan 7\% mewakafkan barang seperti buku namun buku disini 
bukanlah buku yang dikarang sendiri oleh reponden. Selain benda tersebut, 17\% menyebutkan benda lainnya yaitu berupa mukena, karpet untuk masjid, bahan material untuk pembangunan masjid.

Berbeda dengan hasil individu responden yang belum pernah berwakaf, pertanyaan berikutnya yaitu "Apakah dalam keluarga Anda pernah ada yang berwakaf?" pertanyaan tersebut dimaksudkan untuk mencari informasi pada responden apakah dalam keluarganya sudah ada yang berwakaf. Hasilnya 246 responden (76\%) memiliki keluarga yang sudah pernah berwakaf dan sisanya sebanyak 79 responden (24\%) masih belum. Dari hasil tersebut terlihat sudah cukup baik karena meskipun diri responden masih banyak yang belum pernah berwakaf namun setidaknya keluarga sudah ada yang melakukan, karena dari 246 responden yang keluarganya pernah berwakaf hampir 50\% responden diantara itu pernah berwakaf juga. Hal tersebut bisa menjadi dorongan atau motivasi bagi seseorang untuk berbuat hal yang sama dengan orang terdekatnya dalam hal ini keluarga. Dapat di amati juga karena dari 79 responden (24\%) yang keluarganya belum pernah berwakaf 74 responden (93\%) juga belum pernah melakukan wakaf dan 51 responden (58\%) diantaranya juga belum pernah mendengar wakaf Hak Kekayaan Intelektual.

Berdasarkan analisis deskriptif dari pertanyaan pengantar juga dapat disimpulkan ada 60\% responden (194 orang) yang belum pernah berwakaf 24\% diantaranya (47Responden) sama sekali belum pernah mendengar wakaf HKI dan keluarganya pun belum pernah ada yang melakukan wakaf. Sedangkan dari 40\% responden (130 orang) yang pernah berwakaf ada $36 \%$ (47 responden) yang pernah mendengar wakaf HKI dan keluarganya pun pernah berwakaf.

\section{Simpulan}

Sebanyak 62\% dari 324 responden menjawab tidak pernah mendengar adanya wakaf Hak Kekayaan Intelektual dan sisanya sebanyak 121 responden atau 38\% menjawab pernah. Mayoritas jawaban responden yang tidak pernah mendengar tentang wakaf kekayaan intelektual menunjukkan bahwa tingkat pemahaman masyarakat wilayah Jabodetabek mengenai Wakaf HKI masih rendah. Hasil ini juga didukung dengan praktek berwakaf pada masyarakat hanya sebesar $40 \%$. Kondisi ini bisa menjadi dasar para pengambil kebijakan untuk terus mensosialisasikan wakaf kepada masyarakat khususnya wakaf HKI, karena responden dalam penelitian ini dominan berpendapatan lebih dari Rp 4.000 .000 dan 80\% berasal dari perguruan tinggi yang memiliki pengetahuan dan pemahaman yang besar khususnya mengenai wakaf HKI.

\section{Daftar Pustaka}

Abdullah, Mohammad. (2018). Evolution In Waqf Jurisprudence And Islamic Financial Innovation. Journal of Islamic Monetary Economics and Finance, Volume 4, Number 1, August 2018, pp $161-182$. 
Affandy, Bellah Putri. (2017). Analisis Hak Kekayaan Intelektual sebagai objek wakaf dalam upaya meningkatkan perekonomian di Indonesia. Al-Awqaf: Jurnal W akaf dan Ekonomi Islam, 10, (2), Hal. 163-183.

Banindro, Baskoro Suryo. (2015). Implementasi Hak Kekayaan Intelektual (Hak cipta, merek, paten, desain industri) Bidang seni rupa, Kriya, desain grafis dan desai produk. Yogyakarta: Instritute Seni Indonesia

Huda, Nurul., Perdana, W.S., Novarini. (2019). Persepsi Sivitas Akademika Muslim Terhadap Wakaf Uang. Ekspansi:Jurnal Ekonomi, Kenangan, Perbankan dan Akuntansi, 11, (1) Hal. 77-86 DOI: $10.35313 /$ ekspansi.v11i1.1328

Kadir, M. R. A., Sapuan, N. M., \& Ramli, J. A. (2018). Intention to make waqf contribution by muslim employees. Global Business and Management Research, 10(3), 429. Retrieved from https://remote-lib.ui.ac.id:2076/docview/2159618058?accountid=17242

Majid, M. Shabri Abd. (2017). The Motivation Of Muzakki To Pay Zakah: Study At The Baitul Mal Aceh. Signifikan: Jurnal Ilmu Ekonomi, 6 (1), 159 - 176 DOI: 10.15408/sjie.v6i1.4302 159

Mokthar, M. Z. (2016). Perceptions of Universiti Sains Malaysia muslim staff on staff on factors influencing their intention to perform cash waqf. Journal of Islamic Studies and Culture, 4(2), 101-109.

Mubarok, Jaih dan Hasanuddin. 2017. Fikih Mu'amalah Maliyyah, Akad Tabarru', Cet. I. Bandung: Simbiosa Rekatama Media.

Prihatini, F. et. al. (2005). Hukum Islam Zakat dan Wakaf. Jakarta: Kerjasama Penerbit Papas Sinar Mentari dengan Badan Penerbit Fakultas Hukum Universitas Indonesia.

Saidin, O.K. (2004). Aspek Hukum Hak Kekayaan Intelektual, Jakarta: Raja Grafindo Persada. 